\title{
Employees' Perceptions of Environmental Impacts of Tourism Activities in the Okavango Delta, Botswana
}

\author{
Owen Musora*, Joseph Mbaiwa \\ Okavango Research Institute (ORI), University of Botswana, Maun, Botswana \\ Email address: \\ owenmusora $a$ gmail.com (O. Musora), jmbaiwa $a$ ori.ub.bw (J. E. Mbaiwa) \\ ${ }^{*}$ Corresponding author
}

\section{To cite this article:}

Owen Musora, Joseph Mbaiwa. Employees' Perceptions of Environmental Impacts of Tourism Activities in the Okavango Delta, Botswana. International Journal of Hospitality \& Tourism Management. Vol. 2, No. 1, 2018, pp. 13-21. doi: 10.11648/j.ijhtm.20180201.13

Received: August 2, 2018; Accepted: September 11, 2018; Published: October 26, 2018

\begin{abstract}
Tourism is second largest economic activity to mining in Botswana. Botswana tourism is wildlife based and is dependent heavily on water resources. Tourists are attracted by the ecological scenic beauty and wildlife based activities which include camping, game drive, photographing, boating among others mainly in the northern Botswana (Chobe and Okavango Delta). Tourism accommodation facilities are increasing rapidly to cope with the increase in wildlife tourism in the Okavango Delta. Tourism development in contrast erodes the natural environment which it depends on. This paper describes employees' perceptions of environmental impacts of tourism activities in the Okavango Delta, Botswana. Sustainable tourism with emphasis on environmental sustainability forms the theoretical framework of this paper. Data were collected using both primary (employees and key informants interviews) and secondary (intensive review of journals, reports and government publication) data sources. Results indicated that $56.4 \%$ (54) agreed of which $26.2 \%$ (22) strongly agreed that tourism activities are causing environmental impacts in the Okavango Delta. Perceived environmental impacts include pollution (land, water, noise and air), creation of illegal roads and disturbance of plant and animal species by tourism activities. Tourism vehicles especially for game drive are increasing rapidly in the Okavango Delta. This includes tourism private cars, mobile safaris, suppliers of goods and services to accommodation facilities and researchers. Factors resulting in environmental degradation are linked to poor policy implementation by both tourism operators and government officials. Poor monitoring and implementation of environmental policies, plans and laws together with authority manpower, equipment and vehicle shortages propagates environmental impacts in the Okavango Delta. Despite the perceived environmental impact the Okavango Delta is pristine and has rejuvenating properties. This paper suggests that the respective authorities should reinforce, monitor and implement environmental strategies, policies and regulations in collaboration with tourism stakeholders with the aim of sustainable tourism development in the Okavango Delta.
\end{abstract}

Keywords: Sustainable Tourism, Tourism Activities, Employees Perceptions

\section{Introduction}

Tourism is considered one of the world's most vital and tremendously growing economic sectors contributing direct GDP growth of $3.1 \%$ and supporting 6 million net additional jobs. Travel \& Tourism generated US\$7.6 trillion $(10.2 \%$ of global GDP) and 292 million jobs in 2016, equivalent to 1 in 10 jobs in the global economy. The sector accounted for $6.6 \%$ of total global exports and almost $30 \%$ of total global service exports [1]. Modern tourists are nature based due to tourist's sensitivity and courteousness to health care. Tourists globally are vying for nature related active tourism rather than traditional sun, sand and sea. Tourism attractions such as beaches, coral reefs and wildlife viewing are highly preferred resulting in tourism strongly dependent on the natural environment. Healthy ecosystems attract millions of tourists, which in turn bring income and employment to locals residing with the tourist attraction [2]. The growing level of participation in nature based tourism has considerable economic benefits but carries with it environmental costs which might be irreversible.

The total contribution of Travel \& Tourism in Botswana 
economy to GDP was BWP17.779.5mn (USD1, 623.8mn), $10.9 \%$ of GDP in 2016 , and is forecast to rise by $6.5 \%$ in 2017, and to rise by $5.5 \%$ pa to BWP32,204.9mn (USD2,941.3mn), $12.2 \%$ of GDP in 2027. In 2016 the total contribution of Travel and Tourism to employment, including jobs indirectly supported by the industry was $7.1 \%$ of total employment (68,500 jobs). This is expected to rise by $3.7 \%$ in 2017 to 71,000 jobs and rise by $3.5 \%$ pa to 100,000 jobs in 2027 (8.9\% of total) [1]. Botswana tourism is strongly dominant in the northern Botswana which includes Chobe and Ngamil and where the Okavango Delta lies.

The Okavango Delta has global, regional and national importance and recognitions which need to be maintained. The area has vast biodiversity, rare species and natural features such as a unique inland delta (Okavango Delta), a wetland which support ecological systems in the region at large [3]. Its ecological importance is unique and supports rare and endangered species. Tourism growth in the Okavango Delta can be indicated by the increase in numbers of tourism accommodation facilities and camps to copy with the increase in tourist volumes. In 1989, there were 32 accommodation facilities in the Okavango Delta which increased to 63 accommodation facilities in 2001 which represents an increase of $49.2 \%$ in the 13 -year period [4]. The Okavango Delta has approximately 116 established tourism accommodation facilities which have double within a period of 10 years to 2011 according to Department of Tourism, 2011). There is increase in investment in tourism support the UNWTO goal making an economic driver of developing countries. Population density in Okavango Delta Ramsar Site (ODRS) is doubling in every census conducted to 2001 [5]. Census of 2011 shows a gradual increase from 49,642 to 64,864 people (Central Statistics Office, 2011) in the Okavango region which implies that the growth of tourism is coupled with increase in population [6]. Population growth and rural-urban sprawl is related to tourism related job opportunities. Though considerable benefits are being earned from the environment through tourism, there are implied costs that should not be forgotten like pollution, resource stress and deterioration of destination. This paper describes employees` perception of environmental impacts of tourism activities in the Okavango Delta.

\section{Sustainable Tourism}

This paper is informed by the concept of Sustainable Tourism Development viewed by United Nation members as a move to global development and achieving Millennium Development Goals (MDGs). Sustainable tourism is the management of all resources in a way that economic, social and aesthetic needs can be fulfilled while maintaining cultural integrity, essential ecological processes, and biological diversity and life support systems [7].

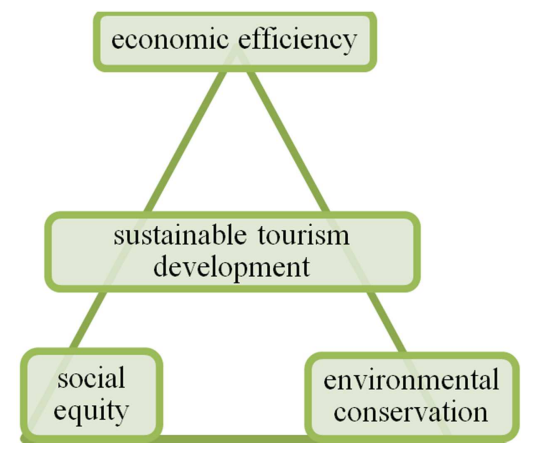

Figure 1. Sustainable Tourism. Adopted from [8].

The paper's main emphasis is on the environmental conservation of the wetland which entails tourism growth in a manner and scale that remains environmentally viable over an infinite period. The Government of Botswana uses the sustainable tourism framework for policy making. The Ministry of Environment, Wildlife and Tourism has the mandate to enforce policies through the Department of Tourism, Department of Environment Affairs and Department of Wildlife and National Parks. The concept of sustainable tourism is a basis for policy framework globally though there is still debate on definition and principles.

Despite the extensive attention paid to sustainable tourism principles over the last twenty years, there still remains a lack of consensus over definitions, theoretical foundations and the extent to which it can be translated into a set of practical policies and measures for the effective planning and management of tourism in the real world [9]. Sustainable tourism has no clearly defined standards and parameters to measure it. It is a theoretical concept which requires further research and varies from one destination to another. Though the shortfalls of sustainable tourism, it acts as a rule of thumb or a benchmark to tourism development nationally, regionally and internationally for policy making. This concept has led to new conservation approaches like ecotourism, responsible tourism that are being used to achieve the sustainable tourism development.

\section{Employees Perceptions}

Tourism impacts are not universal. Very tourism destination is defined according to its life cycle as highlighted by Plog [10]. In line with this, an assessment of tourism establishment employees especially those where tourism activities are undertaken is significant as an indicator to tourism impacts. While different employees may view tourism related impacts in different ways, peoples' perception dependents upon personal variables and characteristics. Many research segregates community members according to how they are uniquely tied to the tourism industry, as well as the host area, in order to understand how their assessment is affected by their individual perceptions $[4,6,11]$.

Employees' levels of satisfaction and their attitudes towards tourism are contingent on their perception of the 
impacts of tourism. A study by Jackson urges that residents who derive benefits from the industry generally support tourism while those who derive little or no benefits from the industry are generally in opposition [11]. In support of this, residents' attitudes are favourable towards the tourism impact than they will probably support additional local tourism development and they will be more hospitable with tourists. People who derive benefits from tourism development generally harbor positive attitudes towards tourism development while those who do not benefit directly from tourism are more inclined to view tourism development in a negative manner [11].

Employees perceive positively if they acquire direct benefits at work places and during their routine interaction with tourists. Workers in the tourism sector perceive negative environmental impacts of tourism like problems of crowding and inaccessible places for local residents during the high season, traffic congestion, noise, pollution, and the environmental destruction due to the construction of tourist facilities. Residents are in agreement that construction facilities destroy the environment, because they have seen major changes during the years and they are able to compare the current situation of the destination to how it was in the past.

A study by Assante in O'ahu, Hawaii on residents' attitudes of sustainable tourism development outlines that many residents feel tourists help increase their quality of life through public services that are mutually beneficial. However, respondents also feel that tourism competes for natural resources (i.e., drinking water) and adds a disproportionate burden to public services (i.e., wastewater disposal). Suggestions by respondents were balancing residents' needs with tourists' needs and the demands of the tourism industry [12].

In Botswana, Okavango Delta, Mbaiwa analysed residents` attitudes towards wildlife conservation and tourism development in the Okavango Delta, Botswana. The study outlines that the majority of residents supported tourists visiting the Okavango Delta because tourists bring income to their villages; tourists' visits promote rural development like creation of roads; create employment opportunities; and, tourists buy their crafts (e.g. baskets). Little consideration was on environmental conservation but on socio-economic contribution of tourism in the Okavango Delta.

\section{Study Area}

The paper is based on a study carried out in the Okavango Delta northwest of Botswana (figure 2). The Okavango Delta is situated in the Northwest of Botswana in Southern Africa and is one of the world's largest inland water systems, starting in Angola, crossing through Namibia, and finally drying up in Botswana.



Adopted from libguides.northwestern.edu/

Figure 2. Okavango Delta map.

The study area is the Okavango Delta situated in Southern Africa in the north west of Botswana. It is a wetland that covers an area of about 16, 000 square kilometers (Tlou, 1985). It is characterized by large amounts of open water and grasslands which sustain human life, plant life, wildlife, birds, insects and various living organisms. In the Okavango
Delta the number of identified species is 1,500 for plants, 85 for fish, 35 for amphibians, 155 for reptiles, 530 for birds, and 160 for mammals (Okavango Delta Exploration, 2018). It covers about $28000 \mathrm{~km}^{2}$ and supports vast biodiversity ranging from aquatic species, terrestrial species and bird life. The Delta was declared protected Ramsar site (Convention 
on Wetlands of International Importance), meaning that the area has a deep social and ecological bearing. It was announced the winner of the world tourism for today and tomorrow awards of 2010 [13]. The tourism visitor numbers has been increasing since 1990s and has potential lead regional tourism in the near future due to its rich wilderness diversity and scenic beauty. The Okavango Delta's wilderness areas are still considered unspoiled and pristine [8]. It is important that the irreplaceable assets continue to be protected if travel and tourism is to be sustained [3].

The Okavango Delta and its ecosystem resources are critically important sources of ecosystem service for people in the basin. A study by Kgathi on livelihood in the Okavango basin classifies livelihood activities into natural resource-based livelihood activities and non-natural resource based. Natural resource based includes arable farming, livestock farming, and collection of veld products, basket making, fishing, and tourism. Non-natural resource-based livelihood activities include social welfare benefits, formal employment, remittances, drought relief initiatives, and rural trade. Important livelihood opportunities for people in the basin are the outcome of a combination of the natural resources available in the area, primarily water, land and living biological resources [14]. Whilst resources are extracted from the natural environment, it is important that all activities are done in a sustainable manner and are effectively controlled and monitored.

\section{Methodology}

A descriptive research design was used to assess employees ' perceptions of environmental impacts of tourism activities in the Okavango Delta. Both qualitative and quantitative methods were used in data collection. Primary data were collected through face to face interviews with key informants, participative observation and tourist questionnaires. Purposive Sampling was used in the selection of five tourism accommodation facilities in the Okavango Delta. The five lodges in different Ngamiland concessions (Maun lodge, Island Safari Lodge and Crocodile CampNG36, Drotsky Cabins - NG01, Xakanaxa Camp - NG28) were chosen. The study purposively chose lodges that have over twenty years in operations and are situated along the shores of the Okavango Delta. Face to face interviews were conducted in long serving employees on tourism accommodation facilities, North West District Council environmental health officers, land board officer, tribal chiefs, and Department of Tourism (DOT), Department of Environment Affairs (DEA) and Department of Wildlife and National Parks (DWNP) officials.

Secondary data were used to identify documented environmental impacts in the Okavango Delta. Descriptive statistics were used in data analysis leading to results and findings of this study. Data were analyzed using the thematic analysis were by similar data were categorized into themes like perception of noise, air, water quality, and cleanliness. Data were presented in tables and bar graphs which gives a theoretical meaning.

\section{Results and Discussion}

\subsection{Employees`General Information of the Respondents}

A total of 85 staff responded to questionnaire with 32 male and 53 female as shown on Table 2. Of the staff, $56.5 \%$ (48) were between 21-30 years old. The education levels of the staff largely dominated by secondary education with $34.1 \%$ (29) and $75.5 \%$ (64) holds a secondary certificate and below. Only $24.5 \%$ (21) hold above certificate with maximum of a diploma constituting $10.6 \%$ of staff. The majority of employees interviewed are local Batswana constituting $97.6 \%$ (83). The management constitute $29.4 \%$ (25) of the people who respondent and was the modal cluster followed by maintenance with $21.2 \%$ (18) and housekeeping with $20 \%$ (17). All employees interviewed were more than six months employed with the same accommodation facilities.

Table 1. Description of employees in accommodation facilities who responded to the questionnaire.

\begin{tabular}{|c|c|c|c|}
\hline Variables & Employees & & \\
\hline \multirow{3}{*}{$\begin{array}{l}\text { Number of } \\
\text { respondents. }\end{array}$} & \multirow{2}{*}{85} & Female & 53 \\
\hline & & Male & 32 \\
\hline & Modal & Frequency & Percentage \\
\hline Modal age & $21-30$ & 48 & 56.5 \\
\hline Education level & Secondary & 29 & 34.1 \\
\hline Country of origin & Batswana & 83 & 97.6 \\
\hline Occupation & Management & 14 & 16.5 \\
\hline
\end{tabular}

\subsection{Tourism Activities}

Research is limited to quantify and identify tourism activities that are currently causing environmental impacts in the Okavango Delta. The amount of environmental impacts of tourism is determined by the number of visitors of tourists in an area. Hence, data from DWNP of 1991 indicates that tourist volumes have been increasing since 1971 accounting 4500 tourists visiting Moremi Game Reserve. In 2010, Moremi Game Reserve accounted for 37082 tourists an increase of $724 \%$ in four decades. This increase is coupled by an increase in tourism activities, increase in level of participation and may be associated with an increase in environmental impacts [6].

In determining tourism activities undertaken, tourists were asked to provide a list of all activities they participated during their tour in the Okavango Delta. Employees were also asked of tourism activities being offered by their companies. Results shown in figure 3 indicate that over $80 \%$ (68) of the tourist participated in game drive, photographing, camping whilst nature-walk, boating (including Mekoro Dugout Canoe), bird watching and, fishing had between 50 $60 \%$ participants. Little participation was on safari hunting, night drives and scenic flight which had below $50 \%$ of tourists. It was observed that all tourists camping at Island Safaris would visit the Okavango Delta and Moremi Game reserve and participate in boating activities, camping among other activities. 


\section{Tourism activities in the Okavango Delta}

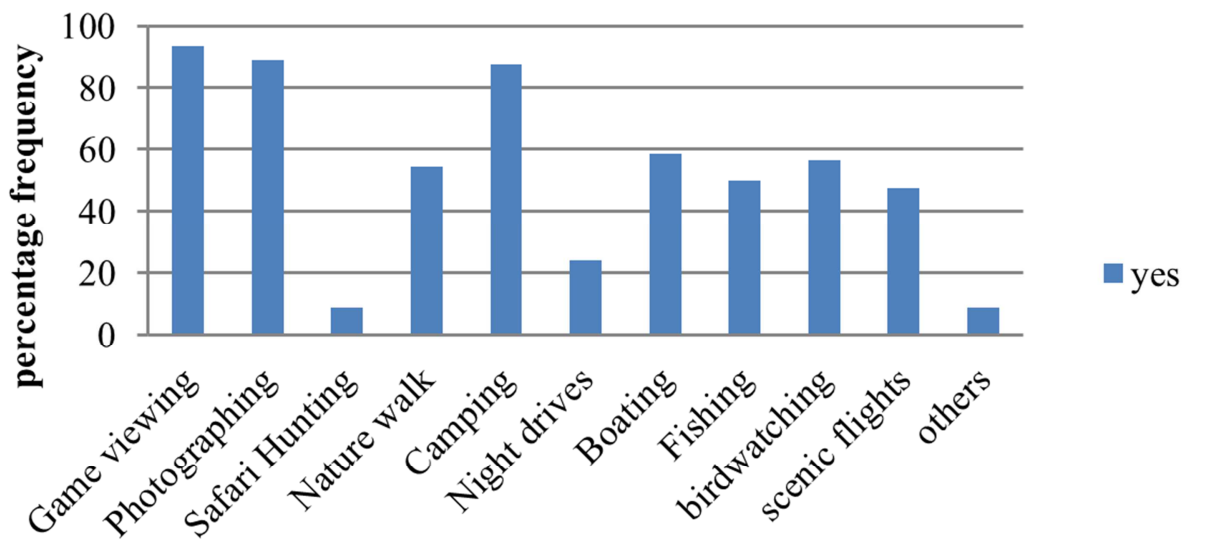

Adopted from (Musora, Mbaiwa, \& Murray-Hudson, 2017)

Figure 3. Tourism activities in the Okavango Delta.

The study indicates that all tourism activities have direct interaction with the ecological environment and are wildlife based. The identified tourist activities are important to tourism development in the Okavango Delta. Increase in visitor numbers and level of participation by tourists have negative environmental impacts in the Okavango Delta.

\subsection{Employees Perception Towards Environmental Impacts of Tourism Activities on Environmental Degradation}

Camping, photographing and game drive are the most common tourism activities in the Okavango Delta as shown in figure 3. Employees responded to questions to assess the environmental impacts attached to those activities. Table 2 shows the response of employees on the effects of tourism activities on natural environment.

The study used a simple linear regression analysis to determine the magnitude of change in perception of employees (Y) as influenced by their education levels (X). A simple linear equation $(y=27.2-1.56 \mathrm{x})$ where $(\mathrm{y})$ is employees 'perceptions and (x) is their education levels. The simple correlation (R- value) is 0.45 , which represented a negative correlation between employees' perceptions and their education levels. This implies that educational levels $(\mathrm{x})$ decrease with employees ' perception $(\mathrm{Y})$. The R-Square $\left(\mathrm{R}^{2}\right)$ value is $20.3 \%$, which indicates the total percentage variations in $\mathrm{Y}$ - variables (perception of employees) as explained $\mathrm{X}$ variables (education levels). There is a negative correlation between the employees' perception and their education levels, which implies that low education levels influence negatively on perceptions of employees. This study indicates that employees in the tourism accommodation facilities are unskilled and on the job trained. 74.3 (63) of employees interviewed hold secondary certificate and below which implies that understanding about waste water management systems might be a challenge. The level of understanding the conservation concept and liquid waste management is limited to the managers.

Table 2. Employees' perceptions on the effects of tourism activities on environmental degradation.

\begin{tabular}{|c|c|c|c|c|c|}
\hline Statement & $\begin{array}{l}\text { Strongly } \\
\text { Disagree }\end{array}$ & Disagree & Neutral & Agree & $\begin{array}{l}\text { Strongly } \\
\text { Agree }\end{array}$ \\
\hline Tourism activities are causing adverse effects on the natural environment & $8(9.4 \%)$ & $18(21.2 \%)$ & $11(12.9 \%)$ & $35(41.2 \%)$ & $13(15.3 \%)$ \\
\hline Game drives has adverse effects on the natural environment & $14(17.9 \%)$ & $9(11.5 \%)$ & $31(39.7 \%)$ & $17(21.8 \%)$ & $7(9 \%)$ \\
\hline Camping has adverse effects on the natural environment & $7(8.3 \%)$ & $19(22.6 \%)$ & $12(14.3 \%)$ & $37(44.0 \%)$ & $9(10.7 \%)$ \\
\hline Does tourism activities result in air pollution & $37(44 \%)$ & $10(12 \%)$ & $17(20 \%)$ & $7(8 \%)$ & $14(16 \%)$ \\
\hline Does tourism activities result in water pollution & $17(20 \%)$ & $17(20 \%)$ & $17(20 \%)$ & $0(0 \%)$ & $34(40 \%)$ \\
\hline Does tourism activities results in land pollution & $25(29.6 \%)$ & $9(11.1 \%)$ & $26(30.6 \%)$ & $9(11.1 \%)$ & $16(18.5 \%)$ \\
\hline
\end{tabular}

Data in Table 2 show how employees perceive the effects of tourism activities on environmental degradation in the Okavango Delta, Botswana. While the majority $56.5 \%$ of employees agrees to the notion, some $30.6 \%$ disagree that tourism activities have adverse effects on the natural environmental. Some $12.9 \%$ of the employees were neutral in their opinion on the statement. 


\subsection{Camping and Environmental Impacts}

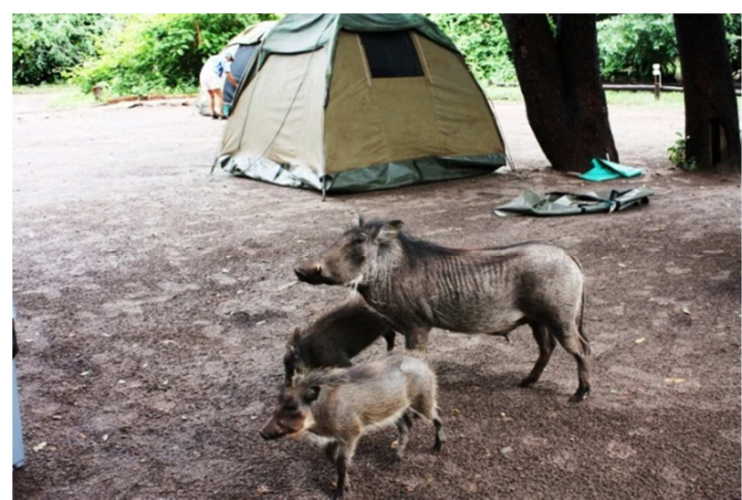

Figure 4. Warthogs on a campsite in the Okavango Delta.

Camping is one of the tourism activities commonly practiced by tourists in the Okavango Delta. It involves the use of outdoor accommodation (refer to figure 4) especially self-extracted tents. Data from Table 2 show that some $54.7 \%$ (46) of employees agrees that camping have adverse effects on the natural environment in the Okavango Delta while $30.9 \%$ (26) where contrary to the opinion. Only $14.3 \%$ (12) are neutral to the opinion that camping has adverse effects on the natural environment in the Okavango Delta. Impacts highlighted by respondents include clearing of land and disturbance of plant and animal species. Other impacts include changes in species composition, breakage and bruising of stems and accelerated erosion. There is a noticeable decline of animal and plant species because of creating camping sites. Observation indicates that in all study sites, exotic flowers, fruits and grass replaced some plants species. Studies like [15] argue that during camping, tourists using the same trail repeatedly trample the vegetation and soil, eventually causing damage that can lead to loss of biodiversity. Other impacts includes loss of ground cover, accelerated erosion, reduced regeneration and changes in species composition. Such damage may be more extensive when visitor numbers increase and frequently stay off established trails.

\subsection{Game Drive and Environmental Impacts}

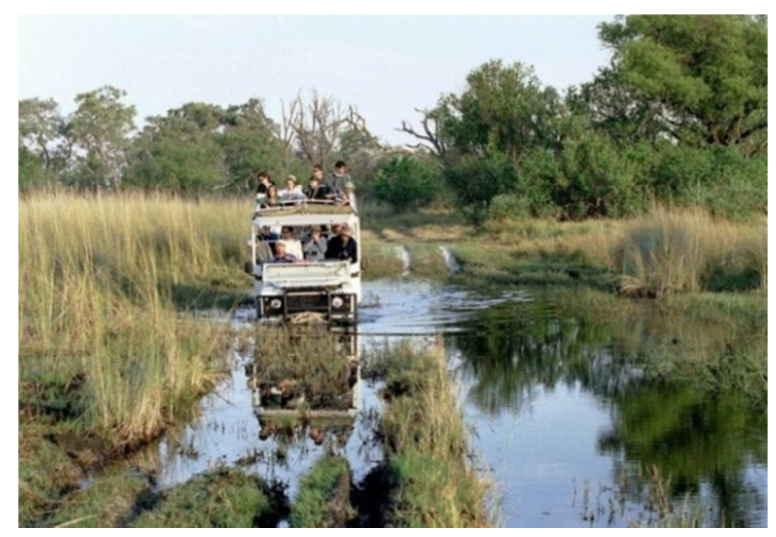

Figure 5. Game drive in the Okavango Delta.

Game drive (refer to fig 5) involves exploring and touring with the use of an open $4 \times 4$ game drive with an expert guide who will explain the sights and sounds. The table 2 shows employees' perceptions of adverse effects of game drive on natural environment in the Okavango Delta. Results show that $39.7 \%$ of employees were neutral about the notion, while some $29.4 \%$ either disagree or strongly disagree. About $31 \%$ of employees agree that game drives have adverse effect on the natural environment and highlighted like creation of illegal roads, potholes and littering. An in-depth interview with Xakanaxa camp manager indicates that there are 91 known potholes between South gate and north gate (a distance of $90 \mathrm{~km}$ ). These potholes were created due to increasing traffic volumes and high participation in tourism activities like game drives. Heavy vehicles like that which transports fuel, food and even tourists create deep potholes which increases the possibility of getting stuck. Heavy vehicles also disturb wildlife through noise and compact the ground. The portholes indicate the failure by the government to maintain roads and tracks and regulating traffic entry in to Moremi Game Reserve. The existence and presence of many deep pothole and poor road influenced driving off roads and illegal roads formation.

\subsection{Illegal Roads and Driving off Roads}

In order to assess formation of illegal roads and the action of driving off roads in the Okavango wilderness employees were interviewed on the roads used during a tour to the wilderness. Tourists have a tendency of driving off roads and searching ways that offers maximum satisfaction. The results are based on the tourists' actions during their tour in the Okavango Delta`s wilderness. Employees' perception results indicates that $61.7 \%$ (48) of employees perceive that tourists use both gazette and illegal roads and tracks during their tour in the Okavango Delta wilderness. These results indicate that tourists have a potential to create illegal roads through driving off roads during game drives in the Okavango Delta. The distance between Xakanaxa and Third Bridge (a distance of $25 \mathrm{~km}$ ) has over $600 \mathrm{~km}$ of tracks and in Moremi Game Reserve there are over $1200 \mathrm{~km}$ of illegal roads. Creation of illegal roads is one of the major environmental impacts of tourism development in the Okavango Delta [4].

Increase in visitor number and motor vehicles entering the Okavango Delta have resulted in creation of illegal tracks and off drives. $4 * 4$ trucks are the most common vehicles used in the Okavango Delta as they can travel on the alluvial sandy deposit and muddy tracks. The creation of illegal roads affects vegetation and reduces the scenic beauty of the Okavango Delta's sensitive areas such as the Xakanaxa in the Moremi game reserve [4]. Roodt highlighted that there are 178 tourist vehicles that use the Xakanaxa area every day in the tourist peak season [16]. This number have increased since there have been a rapid increase in tourism visitors. However the rate of increase of the tourist vehicle is still researchable.

Tourists vehicles tend to create off-road when road are in bad conditions like sandy, muddy or flooded. Some selfdrives have little information of gazetted roads and might 
create roads that satisfy themselves. Some tourists enjoy adventurous trips for example in an informal interview with tourists; they said "it has to be wild for it to be tourism". The practices undertaken might therefore be seeking enjoyment forgetting conservation principles and jeopardizing the importance of aesthetic beauty of the Okavango Delta that tourism requires.

Studies like [17] in Kenya indicate that off-road driving by tourists is common in the Masai Mara and is often perceived as a severe ecological problem. Vehicles can cause damage to vegetation, cause soil compaction and erosion, alter the species composition and influence the recovery of grass species [17]. Around 24,000 vehicles enter Masai Mara annually for an average of 2.5 days each. A study in the 1980 s found that there were conspicuous secondary tracks over extensive areas totaling 15.3 per cent of the reserve's area, and increased vehicle densities and speeds correlated with greater loss of vegetation cover and increased soil compaction on grasslands. The ecological impact of off-road driving is coupled by the negative aesthetic impact of numerous secondary tracks that may impose on the visitor experience and enjoyment [18].

\subsection{Air Pollution}

Some $56 \%$ of employees affirmatively disagree that tourism activities in the Okavango Delta have adverse effects on the air quality while only $24 \%$ of employees agrees to the notion. Only $20 \%$ of employees were neutral to the notion. Similar results were on adverse effects of tourism activities on land pollution in the Okavango Delta. Some $40.7 \%$ of employees disagrees to the notion while about $30 \%$ apiece of the employees both agree and were neutral respectively, with the notion in relation to adverse effects of tourism activities to air quality. Though employees perceive air pollution in the Okavango Delta as pristine, observation shows that some accommodation facilities are polluting the air in various ways like burning of solid waste like plastic, paper and garbage. The study observation indicates that some accommodation facilities in the Okavango Delta have limited access to electricity and therefore fossil fuel like firewood, paraffin lamps and generators are used as a source of energy which is a high source of carbon emission. Fossil fuel is also being used in refrigerators, air conditioners and other important gadgets for tourist's satisfaction. The rate and estimated quantities of carbon emission or carbon footprints is still researchable in the Okavango Delta. According to in-depth interview with key informant, tourism accommodation facilities are contributing heavily in carbon emission through like refrigerators, air conditions, burning of fossil fuel and use of different modes of transport. However, quantifying carbon footprints in the Okavango Delta is still researchable.

\subsection{Noise Pollution}

Data also shows the perception of employees on noise pollution by tourism activities in the Okavango Delta. While
$42.3 \%$ of employees disagree to the notion, $37.4 \%$ of employees either agree or strongly agree, and expressed concerns of noise pollution from tourist vehicles, boats, generators and small planes. Only $19.2 \%$ of employees were neutral to the notion in relation to noise pollution from tourism activities in the Okavango Delta. Employees were interviewed on their perception of noise levels in the Okavango Delta to assess the environmental impacts of tourism activities. Employee results indicate that 38.4\% (10) (26.9\% most and $11.5 \%$ above average) says there is noise pollution in the Okavango Delta. Data collected through an open-ended questionnaire indicate that the main source of noise is boats engine, small aircrafts and tourists' vehicles especially along highways and tracks. Uncontrolled speeding of boats by tourists creates not only noise pollution but also large waves which damages plants and disturbs animal and birds breeding grounds. An observation along the Thamalakane river (outlet of the Okavango Delta), boats travel at high speed especially close to accommodation facilities. According to key informant noise disturbs animals like lions during mating which has long term effect of reducing predator population and therefore ecological imbalance. These results are supported by Mbaiwa who stressed that tourist vehicles are a source of noise pollution and disturbance to the wildlife of the area. Noise is produced by vehicles used during tourism activities like boating, small aircrafts, tourist cars and shuttle buses. Roodts stressed that noise pollution has resulted in hippos in Xakanaxa lagoon to decline in numbers. Noise pollution from engine boats, small engine aircrafts, road vehicles and tourists is common in the Okavango Delta. In addition to causing annoyance, stress, and even hearing loss for humans, it causes distress to wildlife, especially in protected areas like Moremi Game Reserve [4].

\subsection{Water Pollution}

Perception of employees on water pollution from tourism activities had mixed views with $40 \%$ apiece of the employees both agree and disagree to the notion. Only $20 \%$ of employees were neutral to the notion in relation to tourism activities causing adverse effects to water quality in the Okavango Delta. Employees in accommodation facilities perceive that water in the Okavango Delta is polluted and tourism is the major contributor. In-depth interview with employees from one accommodation facility selected indicates that waste disposal pipe is suspected to be connected from the kitchen and dug underground depositing waste water directly to the delta. This practice is against the Waste Management Act of 1998 which stipulate that all waste water should be treated before disposal. Employee perceptions are also based on their day to day behavior and actions in relation to waste water disposal.

Tourism growth is evidenced by increasing in both tourists and local populations which put pressure on the natural environment. It is obvious that as population increase is associated with increase in demand for water and therefore waste production. The majority of the accommodation 
facilities draws water and is located along the Okavango Delta. The disposal for waste water therefore becomes a challenge which needs continuous assessment.

However, it is difficult to measure water quality with peoples' perception. Quantitative approaches are more appropriate and this area is subject to research especially near tourism accommodation facilities in the Okavango Delta. This paper therefore used secondary data on liquid waste management in the Okavango Delta.

\subsection{Land Pollution}

The tourism industry consumers' resource and produce waste. Solid waste common in accommodation facilities includes litter like cans, plastics and other disposals. The increase in tourist numbers is obviously associated with level of consumption and waste production. In order to assess tourists and employee perceptions towards environmental impacts of tourism activities in the Okavango Delta, the study used solid waste management as an indicator with much emphasis on solid waste like paper, plastic, cans, bottles and other solid disposals. Employees' results show that $41.7 \%$ (11) says below average and 33.3\% (9) says above average. This implies that employees perceive the Okavango Delta as a clean environment though population density is increasing. Botswana Rules and Regulations of National Parks and Game Reserve of 2000 stipulate that all solid waste should be transported out of the Okavango Delta wilderness to the administrative village of Maun. This implies that all accommodation facilities should collect, store and transport all solid waste to a landfill situated in Maun. Observations identified different methods of solid waste handling and storage being used by tourism accommodation facilities like burning, composites, locking in a cage than later transported to dumping sites. However some of the methods are not environmentally sound like burning of rubbish. This practice is commonly done in accommodation facilities located in the Okavango Delta wilderness where transporting and handling solid waste is costly. Observation shows that a fire place was prepared for burning of solid waste like plastics, wood and paper. This practice causes air pollution and any negligence can result in bushfires.

In summary, the analysis suggests that most of the respondents were of the opinion that tourism activities have adverse effects on the natural environment in the Okavango Delta, Botswana. Major effects highlighted in informal interviews were on improper disposal of liquid waste, noise pollution, overcrowding of tourist vehicle in protected areas like Moremi Game Reserve resulting in bad condition of roads and tracks, driving off roads and creation of illegal roads and tracks. However, other employees were positive about tourism activities especially on socio-economic benefits that it is contributing to locals.

\section{Conclusion}

This paper has demonstrated that tourism in the Okavango Delta is development rapidly. The Botswana government conceptual view of sustainable tourism focus of economic benefits as tourism is a major economic driver contribution significantly to the nation's GDP. Botswana tourism is wildlife based and is dependent heavily on water resources Tourists are attracted by the ecological scenic beauty and wildlife based activities which include camping, game drive, photographing, boating among others. Tourism accommodation facilities are increasing rapidly to cope with the increase in wildlife tourism in the Okavango Delta. Employees in the tourism industry are commonly Batswana with limited qualification and on the job training.

This paper indicates that the Okavango Delta is being threatened by many factors which require management efforts. Employees perceive that the Okavango Delta is experiencing environmental degradation like water, noise and land pollution. Factors resulting to environmental degradation are linked to poor policy implementation by both tourism operators and government officials. Tourism vehicles especially for game drive are increasing rapidly in the Okavango Delta. This includes tourism private cars, mobile safaris, suppliers of goods and services to accommodation facilities and researchers. Tourism vehicles especially selfdrive has contributed to creation of illegal roads and driving off roads. While roads in the resort area of Maun are considerably good, roads and track to Okavango wilderness are extremely poor. The rate of vehicles getting stuck in mud or sandy is approximately $93.7 \%$ of all tourists visiting areas like Moremi Game Reserve. Much of the blame is on the increase in tourism vehicles which is receiving little management attention from the Department Of Wildlife and National Parks due to unavailability of appropriate support and equipment required especially in protected areas like Moremi Game Reserve. There is no proper monitoring and management of tourism facilities and tourism activities in the Okavango Delta Botswana. Tourist vehicles and mobile safaris competing for best sightseeing vintage points in protected areas like Moremi Game Reserve which has ramped environmental degradation on sites.

Though majority of tourism facilities in the Okavango Delta are dependent on the Okavango Delta`s ecology, there is little efforts to foster sustainable tourism. Dumping of solid and liquid waste in the Okavango Delta is threatening fresh water resources since the waste quality is below BBOS standards. High costs and long distance to Maun which has the only engineered landfill and waste water treatment plant resulted improper waste disposal. Increase in tourism accommodation facilities is resulting in challenges like air pollution. Air pollution caused by burning of fossil fuel by tourism vehicles like boats, small aircraft, cars and trucks. Inaccessibility of electricity has promoted the use of generators by most accommodation facilities in the Okavango Delta. Others facilities have mounted large air conditioners to cope with high temperature along the Okavango Delta.

Poor monitoring and implementation of environmental policies, plans and laws together with manpower shortage, shortage of equipment and vehicles within the Okavango 
Delta propagates environmental impacts in the Okavango Delta. Laws, policies and plans are in place and theoretically sound but its' effectiveness is proven after proper implementation. This suggests that implementation and monitoring procedures need review with an objective of identifying strategies to improve implementation. The Government of Botswana through the respective departments and all stakeholders should collaborate to achieve sustainable tourism development, MDG and Botswana's vision.

\section{References}

[1] WTTC, "Botswana: Travel and Tourism Economic Impact," 2017.

[2] UNWTO, "Jouney to Rio+20. Tourism for Growth and Development," UNWTO, Madrid, 2012.

[3] WTTC, "Botswana: The impacts of travel and tourism on jobs and the economy.," World Travel and Tourism Council, 2007.

[4] J. E. Mbaiwa, "The socio-economic and environmental impacts of tourism development on the Okavango Delta, north-western Botswana," Journal of Arid Environments, pp. 447-467, 2003.

[5] C. H. M. Vanderpost, "Human Sprawl and the African WilderNess of the Okavango.," South African Geographical Journa, pp. 122-130, 2004.

[6] O. Musora, J. Mbaiwa and M. Murray-Hudson, "Tourists perceptions of environmental mpacts of tourism activities on water resources in the Okavango Delta. Botswana," African Journal of Hospitality, Tourism and Leisure, p. 2, 2017.

[7] WTO, " What tourism manages need to know: a practical guide to the development and use of indicators of Sustainable Tourism. Madrid. WTO," WTO, Madrid, 1996.

[8] J. E. Mbaiwa, "The Status of Tourism Development in the Okavango Delta, Botswana," OKACOM, Maun, 2009.

[9] T. a. B. K. Berno, " Sustainable tourism development: the long road from theory to practice.," International Journal of Economic Development 3, pp. 1-18, 2001.

[10] S. Plog, "Why destination ares rise and fall in popularity," Cornell Hotel and Restaurant Quarterly, p. 13, 2001.

[11] L. A. Jackson, "Residents' perceptions of the impacts of special event tourism," Journal of Place Management and Development, pp. 240-255, 2008.

[12] L. Assante, H. Wen and K. Lottig, "An empirical assessment of residents ' attitudes for sustainable tourism development: A case study of O`ahu, Hawaii.," vol. 1, 2009.

[13] WTTC, "Travel and Tourism Economic Impact," World Travel and Tourism Council, pp. 1-14, 2012.

[14] D. Kgathi, D. Kniveton, S. Ringrose, C. Vanderpost, D. Lundqvist and M. Seely, "The Okavango: A river supporting its people, environment and economic development," 2006.
[15] N. Frederico, "Sustainable Tourism, Environmental Protection and Natural Resource Management," Paradise on Earth, February 2002.

[16] V. Roodts, "Ecological Impacts Of tourism on the Xakanaxa area of Moremi Game reserve. Unpublished report. Maun. 59pp," Unpublished, Maun, 1998.

[17] L. Muthee, "Tourist Attitudes and Use Impacts in Maasai Mara National. Ecological Impacts of tourist Use on Habitats and Pressure- point Animal Species," 1992.

[18] N. L.-W. Dilys Roe, "TAKE ONLY PHOTOGRAPHS, LEAVE ONLY: the environmental impacts of wildlife tourism," IIED Wildlife and Development Series, pp. 5-10, 1997.

[19] L. Magole, "Transboundary Diagnostic Analysis of the Botswana Portion of the Okavango River Basin Land Use Planning," Environmental Protection and Sustainable Management in the Okavango Delta, pp. 6-7, 2009.

[20] C. McIvor, Management of Wildlife, Tourism and Local Communities in Zimbabwe, Geneva: United Nations Research Institute for Social Development,, 1994.

[21] P. U. C. Dieke, "Developing Tourism in Africa Consideration, The Development Policy Management Forum 7 (1)," Some Issues for Policy, pp. pp. 25-31, 2000.

[22] B. Keakabetse, "Water shortage in Maun," The Monitor, 07 February 2011.

[23] UNDP, "Building Local Capacity For Conservation and Sustaionable Use of Biodiversity in the Okavango Delta," PIMS 2028, New York, 2005.

[24] S. S. Odunlami, "“an assessment of the ecotourism potential of Yankari National Park, Nigeria."," ECOCLUB.com EPaper Series, pp. 1-5, 2003.

[25] B. L. B. a. S. C. S. Ahn, "Operationalizing Sustainablitity in Regional Tourism Planning: An application of the limit of Acceptable Change Framework, Tourism Planning," Tourism Management, pp. 1-15, 2002.

[26] D. Bond, "Fire In Vegetation of Southern Africa," Cambridge University, Cambridge, 1997.

[27] W. Bond and B. Van Wilgen, "Population and Community Biology Series 14," Fire and Plants, 1996.

[28] B. T. Board, "Ecotourism Best Practices and Guidelines Manual," Botswana Toruism Board, Gaborone, 2001.

[29] W. R. Butler, "Tourism Environemnt and Sustainable Development," Environmental Conservation, pp. 201-9, 1991.

[30] W. R. Butler, The concept of a Tourist Area Life Cycle Of Destination, Pertersburg: Canadian Geograper, 1980.

[31] "Okavango Delta Exploration," July 2018. [Online]. [Accessed 17 July 2018].

[32] J. Mbaiwa and A. Stronza, "The effects of tourism development on rural livelihoods in the Okavango Delta, Botswana," Journal of Sustainable Tourism, p. 635-656, 2010. 